\title{
Evaluation of Antioxidant and Antibacterial properties of Halophila stipulacea Leaves Extracts obtained from (Alwajh) North of Yanbu City
}

\author{
Nehad M. Gumgumjee, Duaa A. Bukhari and A.S. Hajar \\ Department of Biological Sciences, Faculty of Science, King Abdulaziz University, Saudi Arabia.
}

Corresponding Author: Nehad M. Gumgumjee, Department of Biological Sciences, Faculty of Science, King Abdulaziz University, Saudi Arabia.

Received date: 11 March 2018, Accepted date: 15 June 2018, Online date: 20 June 2018

Copyright: (C) 2018 Nehad M. Gumgumjee. This is an open-access article distributed under the terms of the Creative Commons Attribution License, which permits unrestricted use, distribution, and reproduction in any medium, provided the original author and source are credited.

\begin{abstract}
In this present investigation the antibacterial activity of Halophila stipulacea against seven bacterial pathogens strains (Bacillus subtilis, Methicillin-Resistant Staphylococcus aureus, Staphylococcus aureus, Micrococcus luteus, Escherichia coli, Klebsiella pneumoniae and Pseudomonas aeruginosa using different solvent extracts. The results showed that ethanol leaves extracts appeared the highest activity against Pseudomonas aeruginosa while it's appeared the lowest activity against Escherichia coli. . However, the aqueous extract was not active against all tested bacteria except $P$. aeruginosa. The antioxidant activity of Halophila stipulacea showed high percentage of DPPH radical scavenging activity was (79.10\%).
\end{abstract}

Key words: Antibacterial; Seagrass; Pathogens; Halophila stipulacea; antioxidant.

\section{INTRODUCTION}

As a result of antibiotic resistant microorganisms, infectious diseases remain one of the major causes of death. The rate at which microbial organisms continue to be resistant is significantly high globally (Schmitz et al., 1999). Consequently, the elevated level of resistance of pathogens and the ineffectiveness of the antibiotics has created a need to find other options (Ravikumar et al., 2010a). Manufacturing of new drugs, which are effective and without any other consequences is very necessary in order to deal with these issues. Overall, in order to come up with stronger antibiotics for killing the bacteria, viruses, fungi, and other harmful microorganisms, marine plants, such as mangroves, seaweeds, seagrasses, and marine sponges have been subjected to deep research (Ravikumar et al., 2009\&2011).

Seagrasses are immersed marine angiosperms and it was grown increasable in tidal and subtidal areas in all seas except in the Polar Regions. Biomass from the seagrasses is used as a human food especially by coastal populations (Hemminga and Duarte, 2000). Seagrasses has widely useful and uses in medicine to various ailments, including skin problems, fiver, muscle pains, and stomach aches, among other ailments in folk medicine (de la Torre-Castro and Rönnbäck, 2004).

Seagrasses belonging to the genus Halophila are widely distributed along the western coasts of the Indian Ocean, Red Sea and South-eastern Florida coasts (Den Hartog, 1970). A number of seagrasses have been highly associated with antibacterial activities. For instance, Halophila stipulacea, Cymodocea serrulata and Halodule pinifolia (Kannan et al., 2010). Produce of bioactive compounds from H. stipulacea extracts had been contained potential therapeutic interest. Moreover, the production of antimicrobial activity was occurred from this seagrass for synthesize bioactive secondary metabolites. It is approned that there are many producers of natural compounds unexplored in water environment that could be potential sources to reduce or control of bacterial diseases (Özbay and Alim, 2009).

Also, these findings have fortified the development of replacement antioxidants of natural origin (Huang and Wang, 2004). Many natural antioxidants were isolated from various natural resources such as oilseeds, grains, vegetables, spices, and herbs (Ramarathnam et al., 1995). Seagrasses had contained bioactive compounds had been against bacteria (Harrison and Chan, 1980).

The present study was undertaken to investigate the antioxidant and antibacterial activity of seagrass, Halophila stipulacea which collected from the north of Yanbu city (Alwajh) in the Red Sea of Saudi Arabia against some pathogenic bacterial strains.

\section{MATERIALS AND METHODS}

Sample collection:

Fresh leaves of Halophila stipulacea were collected from the intertidal region of the north Yanbu city (Alwajh) $24^{\circ} 17^{\prime} 30.3^{\prime \prime} \mathrm{N} 37^{\circ} 39^{\prime} 15.1^{\prime \prime} \mathrm{E}$ (Lat.) then, immediately brought to the laboratory in sterile plastic bags containing water to prevent evaporation.

\section{Extraction:}

According to Boreu and Derevici, (1978), ten Grams of dried seagrasses leaves samples. Extraction was done by adding $100 \mathrm{ml}$ of distilled water or organic solvents (Ethanol, Ethyl acetate and Chloroform) $(1: 10 \mathrm{~W} / \mathrm{V})$ using separating funnel and shaking for 72 hours at room temperature. Their solvents extract was filtered through Whatman filter paper (No.1) and the organic solvents were evaporated under reduced pressure at $40^{\circ} \mathrm{C}$ until dryness. The sea grass leaves extracts were all dissolved in DMSO and kept in small closed vials at low temperature $4^{\circ} \mathrm{C}$.

Bacterial Strains:

Seven tested bacterial strains were (four Gram-positive: Bacillus subtilis (ATCC11774); Methicillin-Resistant Staphylococcus aureus (MRSA) (ATCC977); Staphylococcus aureus (ATCC29213) and Micrococcus luteus (ATCC4698) and three Gram-negative: Escherichia coli (ATCC8739); Klebsiella pneumoniae 
Citation: Nehad M. Gumgumjee, et al., Evaluation of Antioxidant and Antibacterial properties of Halophila stipulacea Leaves Extracts obtained from (Alwajh) North of Yanbu City. Australian Journal of Basic and Applied Sciences, 12(6): 8-11.

(ATCC700603) and Pseudomonas aeruginosa (ATCC27853). Those strains were provided by Microbiologics® USA. The bacteria were obtained from King Abdulaziz Hospital, Jeddah, Saudi Arabia.

Antibacterial Activity:

Antibacterial activities of plant extracts were tested against different test microorganisms using agar well diffusion method described by Egorove (1985). Petri plates were prepared pouring $20 \mathrm{ml}$ of Mueller-Hinton agar for bacteria. A suspension of testing microorganisms was add to Mueller-Hinton agar for bacteria.

Using sterile cork borer, three wells of $5 \mathrm{~mm}$ diameter in agar plate were made. Each well was filled with $50 \mu \mathrm{l}$ of the tested leaves plants extracts. Plates were left for one hour at $4^{\circ} \mathrm{C}$ and then incubated for $24 \mathrm{~h}$ at $37^{\circ} \mathrm{C}$ for bacteria. Inhibition zones (including the diameter of disc) were measured. The obtained results were compared with DMSO as a negative control and with different antibiotic as a positive control (Agwa et al., 2000).

\section{Antibiotics Used:}

Ticarcillin (TC) $25 \mu \mathrm{g}$, Cefepime (CPM) $30 \mu \mathrm{g}$, Gentamicin (GM) $10 \mu \mathrm{g}$, Amikacin (AK) $30 \mu \mathrm{g}$, Imipenem (IMI) $10 \mu \mathrm{g}$, Piperacillin (PRL) $100 \mu \mathrm{g}$, Ampicillin (AP) $10 \mu \mathrm{g}$, Augmentin (AUG) $30 \mu \mathrm{g}$, Cefoxltin (FOX) $30 \mu \mathrm{g}$, Cephalothin (KF) $30 \mu \mathrm{g}$ and Cotrimoxazole (TS) $25 \mu \mathrm{g}$. From Mast Diagnostics Mast Group Ltd. Merseyside U.K.

Synergism between Plant Extracts and Antibiotics:

Each bacteria will inoculate on the surface of Mueller-Hinton Agar plates. Subsequently, the disc (diameter $=5 \mathrm{~mm}$ ) will place on the surface of each inoculated plate and then add $20 \mu \mathrm{l}$ (microliter) of extract (at concentration of $200 \mathrm{mg} / \mathrm{ml}$ ), to identify synergies effect between the plant extract and antibiotics were mixed and put together on a filter paper disc which was left for one hour to dry. The plates will incubate at $37^{\circ} \mathrm{C}$ for $24 \mathrm{~h}$. The diameters of clearing zones will measure (Mahmoud, 2013).

DPPH radical-scavenging activity:

The scavenging effects of samples for DPPH radical were monitored according to the method of (Yen and Chen, 1995). 1-50 $\mu 1$ of extract, will add to $5 \mathrm{ml}$ of $0.004 \%$ ethanolic solution of DPPH. After for $50 \mathrm{~min}$ of incubation at dark, the absorbance will read against a blank at $517 \mathrm{~nm}$. Inhibition free radical DPPH (diphenylpicrylhydrazyl) in percent $(I \%)$ will calculate as in Eq:

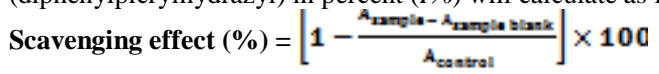

Results:

The antibacterial activity of $H$. stipulacea leaves extracts on seven bacterial pathogens strains were presented in table 1.

The results reveal that the antibacterial activity of $H$. stipulacea seagrass leaves extracts. All three tested solvents extracts were inhibited the growth of all bacterial pathogens by different zones. The highest zone of inhibition by petroleum ether extract against $P$. aeruginosa was showed (20.67 mm) followed by $(17.33 \mathrm{~mm})$ with $B$. subtilis in the same extract. The lowest zone of inhibition by ethyl acetate extract against $S$. aureus was obtained (12 mm). No inhibition zone was seen by aqueous extract except in $P$. aeruginosa which was appeared $(15.67 \mathrm{~mm})$ zone.

Table 1: Antibacterial activity of Halophila stipulacea seagrasses leaves extracts against Gram-positive and Gram-negative bacteria, tested using well diffusion assay.

\begin{tabular}{|l|l|l|l|l|}
\hline Tested Bacteria & Diameter of the inhibition zone (mm) Mean \pm SD & Distilled water \\
\cline { 2 - 5 } & Ethanol & Chloroform & Ethyl acetate \\
\hline $\begin{array}{l}\text { Bacillus subtilis } \\
\text { ATCC11774 }\end{array}$ & $17.33 \pm 0.58$ & $16.33 \pm 0.58$ & $14.67 \pm 0.58$ & $0 \pm 0.0$ \\
\hline $\begin{array}{l}\text { Methicillin-Resistant Staphylococcus aureus } \\
\text { ATCC977 }\end{array}$ & $16.33 \pm 0.58$ & $15 \pm 0.0$ & $12.67 \pm 0.58$ & $0 \pm 0.0$ \\
\hline $\begin{array}{l}\text { Micrococcus luteus } \\
\text { ATCC4698 }\end{array}$ & $16 \pm 0.0$ & $15 \pm 0.0$ & $13.33 \pm 0.58$ & $0 \pm 0.0$ \\
\hline $\begin{array}{l}\text { Staphylococcus aureus } \\
\text { ATCC29213 }\end{array}$ & $14.67 \pm 0.58$ & $13.33 \pm 0.58$ & $12 \pm 0.0$ & $0 \pm 0.0$ \\
\hline $\begin{array}{l}\text { Escherichia coli } \\
\text { ATCC8739 }\end{array}$ & $14.67 \pm 0.58$ & $13.67 \pm 0.58$ & $13.33 \pm 0.58$ & $0 \pm 0.0$ \\
\hline $\begin{array}{l}\text { Klebsiella pneumonia } \\
\text { ATCC700603 }\end{array}$ & $16 \pm 1.0$ & $16 \pm 0.0$ & $14.33 \pm 0.58$ & $0 \pm 0.0$ \\
\hline $\begin{array}{l}\text { Pseudomonas aeruginosa } \\
\text { ATCC27853 }\end{array}$ & $20.67 \pm 0.58$ & $18.33 \pm 0.58$ & $17.33 \pm 0.58$ & $15.67 \pm 1.16$ \\
\hline
\end{tabular}

Evaluation of the Synergistic Effect:

In vitro synergism between the most active solvents of $H$. stipulacea and antimicrobial drugs utilized against $P$. aeruginosa shown in table 2 . H. stipulacea leaves extract had a interactive effect which examined on antibiotics and the highest interactive effect of the most active ethanolic extract was Imipenem (IMI), Piperacillin (PRL) and Cefoxltin (FOX) (38.5, 31.5 and 30.5 respectively). The rest of antibiotics have shown antagonistic effects.

\section{Antioxidant activity assay:}

DPPH is accepting an electron or hydrogen radical to become a stable substance molecule. Therefore, the effect of antioxidants on DPPH free radical scavenging is may be caused to their hydrogen donating ability. When, DPPH solution is mixed with a substrate acting as hydrogen atom donor to obtained stable non-radical DPPH form with the change of the violet color to pale yellow (Molyneux, 2004). In the present study H. stipulacea leaves extract showed higher DPPH radical scavenging activities was recorded in different concentration $(20,40,60,80,100 \mu \mathrm{g} / \mathrm{ml})$ compared with ascorbic acid. Oxidative effect of $H$. stipulacea leaves extract and the standard ascorbic acid with increase in dose shown in Table 3 . Similar to our results, Ragupathi et al., (2012) found that the radical scavenging activity of the ethanol extract from leaves of Halophila stipulacea and ascorbic acid increased markedly with increase of concentrations. 
Citation: Nehad M. Gumgumjee, et al., Evaluation of Antioxidant and Antibacterial properties of Halophila stipulacea Leaves Extracts obtained from (Alwajh) North of Yanbu City. Australian Journal of Basic and Applied Sciences, 12(6): 8-11.

Table 2: Synergism between Antibiotics and Ethanolic Extracts of $H$. stipulacea against P. aeruginosa.

\begin{tabular}{|c|c|c|c|}
\hline Antibiotics Names & $\begin{array}{lll}\begin{array}{l}\text { Effect } \\
(\mathrm{mm})\end{array} & \text { of Antibiotics } \\
\end{array}$ & $\begin{array}{l}\text { Ethanol Extract } \\
(\mathrm{mm})\end{array}$ & $\begin{array}{l}\text { Ethanol Extract + Antibiotic } \\
(\mathrm{mm})\end{array}$ \\
\hline Ticarcillin (TC) & 24 & \multirow[t]{11}{*}{20.67} & 23.5 \\
\hline Cefepime (CPM) & 15.5 & & 15 \\
\hline Gentamicin (GM) & 24 & & 22 \\
\hline Amikacin (AK) & 23 & & 21.5 \\
\hline Imipenem (IMI) & 35 & & 38.5 \\
\hline Piperacillin (PRL) & 28.5 & & 31.5 \\
\hline Ampicillin (AP) & 18 & & 16.5 \\
\hline Augmentin (AUG) & 27 & & 26.5 \\
\hline Cefoxltin (FOX) & 26 & & 30.5 \\
\hline Cephalothin (KF) & 21 & & 24.5 \\
\hline Cotrimoxazole (TS) & 22 & & 24.5 \\
\hline
\end{tabular}

Table 3: DPPH radical scavenging activity of ascorbic acid, and extract of Halophila stipulacea leaves.

\begin{tabular}{|l|l|}
\hline \multicolumn{2}{|c|}{$\%$ percentage of inhibition } \\
\hline Ascorbic acid & $88.1 \%$ \\
\hline Concentration of Halophila stipulacea leaves extract & $70.97 \%$ \\
\hline 20 & $72.28 \%$ \\
\hline 40 & $74.89 \%$ \\
\hline 60 & \\
\hline 80 & $76.05 \%$ \\
\hline 100 & $79.10 \%$ \\
\hline
\end{tabular}

\section{Discussion:}

Due to the increasing of the resistance rate of microorganisms on the antibiotic drugs in the recent past, the field of clinical treatment for infectious diseases has faced big problems diseases (Ravikumar et al., 2010). There are various reports on the ability of seaweeds, mangroves and other marine plants to kill microorganism activities while little has been written about the global seagrasses and there is also minute information about those (Kannan et al., 2010). The purpose from this investigation is to evaluate and compare how and potential of seagrass extracts in the synthesis of bioactive substances, which can be used for therapeutic purposes. The exhibition of antimicrobial activities in the seagrass demonstrated their ability to produce bioactive secondary metabolites.

The antibacterial activity of three different leaves extracts of $H$. stipulacea against seven bacterial pathogens strains were effective. Among them, ethanol extract was the more effective against $P$. aeruginos $a$ than other extracts; this showed that ethanol is suitable for extracting active compounds from seagrass. These findings were supported by the earlier studies which suggested that the methanolic extract of Enhalus acoroides produced a stronger effect against $P$. aeruginosa, K. pneumoniaeand S. aureus when compared to the hexane extract (Alam et al., 1994). This study demonstrated that the best antimicrobial activity was in the ethanoic extract, which concurred with other earlier reports (Umamaheshwari et al., 2009) and the ethanolic and methanolic extractions of the seagrasses Halophila ovalis and Halodule pinafolia were preferable than the other tested extracts because their better inhibition zones against tested bacteria (Mani et al., 2012).

Our most recent study showed that Gram-negative bacteria were more sensitive compared to the Gram-positive bacteria. This concurred with the findings of a certain report that there was an anti-fouling of various marine organisms against Bacillus and Pseudomonas sp. (Bhosale et al., 2002). The inconsistencies of the extracts in the antibacterial activity can be as a result of the variations of antimicrobial agents from species to species (Lustigman and Brown, 1991).

The lowest antimicrobial effect was observed in the extracts of ethyl acetate of $H$. stipulacea. Also, the results suggested that $P$. aeruginosa had a moderate sensitivity rate when the aqueous extracts were used against them, unlike the other microorganisms. This agrees with another report that aqueous extracts of $C$. rotundata showed very poor activity with all the test bacteria (Mani et al., 2012).

The natural antioxidant from Cymodocea rotundata had contains saponins, tannins, flavonoids, terpenoids and alkaloids have effect against microorganism activity (Okeke et al., 2001 and Ergene $e t$ al., 2006). Moreover, the study assessed the photochemical properties of hexane, chloroform, ethyl acetate, ethanol and aqueous extracts of the three glycosides which have saponins, and tannins. All the three seagrasses: Cymodocea serrulata, Halophila ovalis and Halodule pinifolia lacked sugars and quinine (Sangeetha and Asokan, 2016).

Plants had contained compounds to be synergistic enhancers against microorganism have been found and it may not have any antimicrobial properties alone, but when it was taken with drugs they promote the effects of these drugs (Rakholiya and Chanda, 2012). One of those effective accesses to defeat the bacterial resistance is restoration of antibiotic activity during the interactive action of antibacterial substrate from natural and chemical factors (Stefanovic et al., 2011). In present study, synergism between the most active plant of H. stipulacea leaves extracts and antimicrobial drugs utilized against p.aeroginosa showed beneficial synergistic such as Imipenem (IMI), Piperacillin (PRL) and Cefoxltin (FOX). The rest of antibiotic have shown antagonistic effects. Similar to our results, Adwan and Mhanna, (2008) showed the synergistic or antagonistic effect between antibiotic and bioactive plant extracts of Psidium guajava, Rosmarinus officinalis, Salvia fruticsa, Majorana syriaca, Ocimum basilucum, Syzygium arromaticum, Laurus nobilis and Rosa damascene. From the obviously results it could be recommended and concluded that the sea grass $H$. stipulacea had contained strong natural antioxidant properties due to the total phenolic acids and flavonoids compounds are the major contributor for the antioxidant capacities of seagrasses. Moreover, we are studies being carried out on other species of seagrasses of different homeland in order to provide more comprehensive data on the antioxidant activity found in seagrass.

\section{Conclusion:}

Our study showed that the ethanolic leaves extract of seagrass $H$. stipulacea have better performance than other solvent extracts. It is evident that $P$. aeruginosa is more sensitive bacteria than others. Hence, the seagrass $H$. stipulacea will be used as a source of extraction of new antibiotic compounds in the 
future. The result from this study forms a basis for further studies of the potent seagrass so as to isolate the compounds responsible for the antibacterial and antioxidant activities.

\section{REFERENCES}

Adwan, G. and M. Mhanna, 2008. Synergistic effects of plant extracts and antibiotics on Staphylococcus aureus strains isolated from clinical specimens. Middle-East Journal of Scientific Research, 3(3): 134-139.

Agwa, A., M. Aly and R. Bonalt, 2000. Isolation and characterization of two Streptomyces species produced non polyenic antifungal agents. Journal Union Arab Biologi, 7: 62-82.

Alam, K., T. Agua, H. Maven, R. Taie, K.S. Rao and I. Burrows, 1994. Preliminary screening of seaweeds, seagrass and lemongrass oil from Papua New Guinea for antimicrobial and antifungal activity. Pharmaceutical Biol., 32(4): 396-9.

Bhosale, S.H., V.L. Nagle and T.G. Jagtab, 2002. Antifouling potential of some marine organisms from India against species of Bacillus and Pseudomonas. Marine Biotechnol., 4: 111-8.

Boeru, V. and A. Derevici, 1978. Some chemical and physical data on Romania propolis. Apimondia "propolis" Bucharest, 19-26.

de la Torre-Castro, M. and P. Rönnbäck, 2004. Links between humans and seagrasses - An example from tropical East Africa. Ocean and Coastal Management, 47: 361-387.

Den Hartog, C., 1970. The Sea-grasses of the World. North-Holland, London.

Egorove, N., 1985. Antibiotics scientific approach. Mirpublishers Moscow.

Ergene, A., P. Guler, S. Tans, S. Miric, E. Hamzaoglu and A. Duran, 2006. Antibacterial and antifungal activity of Heracleum sphondylium subsp. artvinense, Afirican J. Biotech., 5: 1087-1089.

Harrison, P.G. and A.T. Chan, 1980. Inhibition of the growth of microalgae and bacteria by extracts of eelgrass (Zostera marina) leaves. Mar Biol., 61: 2126.

Hemminga, M.A. and C.M. Duarte, 2000. Seagrass ecology. New York. pp: Cambridge University Press; 298.

Huang, H.L. and B.G. Wang, 2004. Antioxidant capacity and lipophilic content of seaweeds collected from the Qingdao coastline. J Agric Food Chem., 52: 4993-4997.

Kannan, R.R., R. Arumugam and P. Anantharaman, 2010. Antibacterial potential of three seagrasses against human pathogens. Asian Pacific Journal of Tropical Medicine, 890-893.

Lustigman, B. and C. Brown, 1991. Antibiotic production by marine algae isolated from the New York/New Jersey Coast. Bull Environ Contam Toxicol., 46: $329-35$

Mahmoud, M.J., 2013. The antibacterial effect of some medicinal plant extracts and their synergistic effect with antibiotic and non-antibiotic drugs. Thesis, Islamic University-Gaza, Palestine.

Mani, A.E., V. Bharathi and J. Patterson, 2012. Antibacterial Activity and Preliminary Phytochemical Analysis of Sea Grass Cymodocea rotundata. International Journal of Microbiological Research, 3(2): 99-103.

Molyneux, P., 2004. The use of the stable free radical diphenylpicrylhydrazyl (DPPH) for estimating antioxidant activity. Songklankarin J. Sci. Technol., 26(2): 211-219.

Okeke, M.I., C.U. Iroegbu, E.N. Eze, A.S. Okoli and C.O. Esimone, 2001. Evaluation of extracts of the root of Landolphia owerrience for antibacterial activity. J. Ethnopharmacol., 78: 119-127.

Özbay, H. and A. Alim, 2009. Antimicrobial activity of some water plants from the northeastern Anatolian region of Turkey. Molecules, 14: 321-328.

Rakholiya, K. and S. Chanda, 2012. In vitro interaction of certain antimicrobial agents in combination with plant extracts against some pathogenic bacterial strains. Asian Pacific Journal of Tropical Biomedicine, 2(2): S876-S880.

Ramarathnam, N., T. Osawa, H. Ochi and S. Kawakishi, 1995. The contribution of plant food antioxidants to human health. Trends Food Sci Technol, 6: 7582.

Ravikumar, S., S. Jacob Inbaneson, P. Suganthi and M. Gnanadesigan, 2011. In vitro antiplasmodial activity of ethanolic extracts of mangrove plants from South East coast of India against chloroquinesensitive Plasmodium falciparum. Parasitol Res., 108: 873-878.

Ravikumar, S., G. Ramanathan, S. Jacob Inbaneson and A. Ramu, 2010. Antiplasmodial activity of two marine polyherbal preparations from Cheatomorpha antennina and Aegiceras corniculatum against Plasmodium falciparum. Parasitol Res. doi: 10. 1007/ s00436-010-2041-5.

Ravikumar, S., G. Ramanathan, M. Subakaran and S. Jacob Inbaneson, 2009. Antimicrobial compounds from marine halophytes for silkworm disease treatment. Int. J. Med. Sci., 1(5): 184-191.

Ravikumar, S., N. Thajuddin, P. Suganthi, S. Jacob Inbaneson and T. Vinodkumar, 2010a. Bioactive potential of seagrass bacteria against human bacterial pathogens. J. Environ. Biol., 31: 387-389.

Rengasamy, R., A. Rajasekaran, G. Micheline and A. Perumal, 2012. Antioxidant activity of seagrasses of the Mandapam coast, India. Pharmaceutical Biology. ISSN: 1388-0209 (Print) 1744-5116.

Sangeetha, J. and S. Asokan, 2016. Phytochemical analysis and antibacterial activity of the three different seagrass extracts. International Journal of Advanced Research, 4(5): 1451-1457.

Schmitz, F.J., J. Verhoef and A.C. Fluit, 1999. Prevalence of resistance to MLS antibiotics in 20 European University hospitals participating in the European SENTRY surveillance program. J Antimicrob Chemother, 43: 783-792.

Stefanovic, O., M.S. Stankovic and L. Comic, 2011. In vitro antibacterial efficacy of Clinopodium vulgare L. extracts and their synergistic interaction with antibiotics. Journal of Medicinal Plants Research, 5(17): 4074-4079.

Umamaheshwari, R., G. Thirumaran and P. Anantharaman, 2009. Potential antibacterial activities of seagrasses from Vellar Estuary; Southeast coast of India. Advances in Biological Research, 3(3-4): 140-143.

Yen, G.C. and H.Y. Chen, 1995. Antioxidant activity of various tea extracts in relation to their antimutagenicity. J. Agric. Food Chem., $43: 27-37$. 